\title{
The Performance of Islamic Banking in Malaysia
}

Nur Tasneem Fazam, Nurshahira Abd Samad, Wan Nur Izana Wan Mohd Zawawi, Wan Damia Aisyah Wan Mohamad Tajeri, Wan Nur Syafiyyah Asma' Hairul Anuar, Amir Imran Zainoddin

To Link this Article: http://dx.doi.org/10.6007/JARBSS/v11-i11/10900 DOI:10.6007/IJARBSS/v11-i11/10900

Received: 11 September 2021, Revised: 05 October 2021, Accepted: 25 October 2021

Published Online: 07 November 2021

In-Text Citation: (Fazam et al., 2021)

To Cite this Article: Fazam, N. T., Samad, N. A., Zawawi, W. N. I. W. M., Tajeri, W. D. A. W. M., Anuar, W. N. S. A. H., \& Zainoddin, A. I. (2021). The Performance of Islamic Banking in Malaysia. International Journal of Academic Research in Business and Social Sciences, 11(11), 661-672.

Copyright: $\odot 2021$ The Author(s)

Published by Human Resource Management Academic Research Society (www.hrmars.com)

This article is published under the Creative Commons Attribution (CC BY 4.0) license. Anyone may reproduce, distribute, translate and create derivative works of this article (for both commercial and non-commercial purposes), subject to full attribution to the original publication and authors. The full terms of this license may be seen at: http://creativecommons.org/licences/by/4.0/legalcode

Vol. 11, No. 11, 2021, Pg. $661-672$

Full Terms \& Conditions of access and use can be found at http://hrmars.com/index.php/pages/detail/publication-ethics 


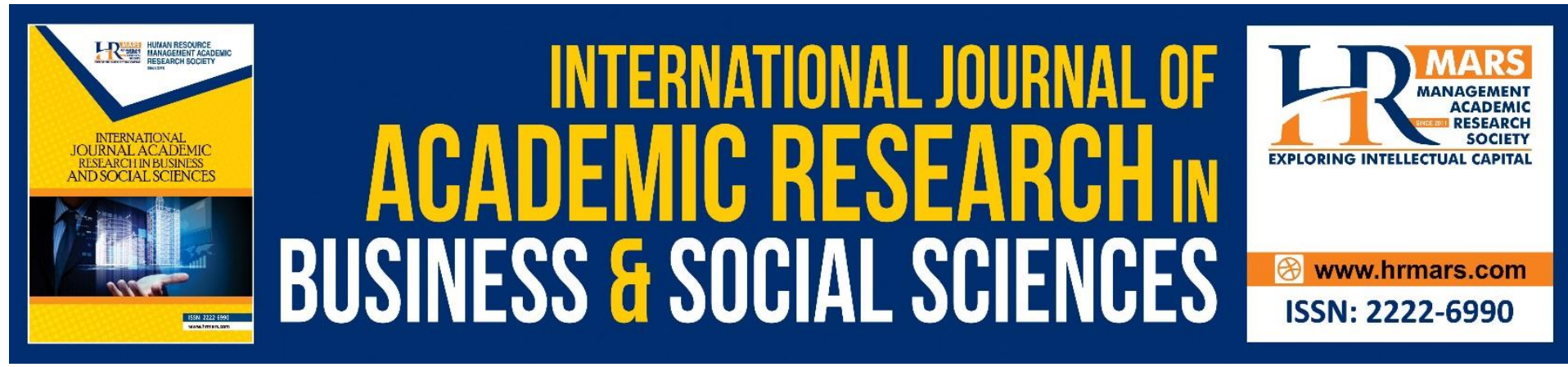

\title{
The Performance of Islamic Banking in Malaysia
}

\author{
Nur Tasneem Fazam, Nurshahira Abd Samad, Wan Nur Izana \\ Wan Mohd Zawawi, Wan Damia Aisyah Wan Mohamad Tajeri, \\ Wan Nur Syafiyyah Asma' Hairul Anuar, Amir Imran Zainoddin \\ Faculty of Business and Management, Universiti Teknologi MARA Cawangan Johor, Kampus \\ Segamat, 85000 Segamat, Johor, Malaysia \\ Email: amirimran@uitm.edu.my
}

\begin{abstract}
The aim of this research is to determine the financial performance of Islamic banking in Malaysia. The research is performed by analyzing return on asset (ROA) and return on equity (ROE) as dependent variables to see the relationship between bank size, risk management and gross domestic product (GDP) as independent variables to the bank. Information for this analysis was collected from related databases and annual reports. This study uses secondary data from top three (3) Islamic banks in Malaysia between the years 2011 to 2020 which are Maybank Islamic Berhad, CIMB Islamic Bank Berhad and Bank Islam Malaysia Berhad. The balanced panel data is regressed using the Pooled Ordinary Least Square Model. Bank size shows insignificant value because it indicates that small banks performed better compared to the big one. Risk management shows the same result when an increase in debt is connected with higher credit risk due to higher possibility of uncollectible sums owed. GDP shows insignificant results because some clients are unable to retain and hold earnings for a lengthy period caused by regulatory limitations, less business activity and charged less proportion of tax. The findings show these variables do not have a major impact on banking profitability. (200 words)
\end{abstract}

Keyword: Credit Risk, Bank Size, GDP, ROA and ROE

\section{Introduction \& Background of Study}

Every nation has financial institutions that represent the country's financial guidelines and ensure economic development as well as money management. Financial companies are in charge of managing and controlling all funding capital. The presence of financial institutions aids in the development of a country's economic operation. There are three categories of financial institutions in Malaysia at the moment which are conventional banking, investment banking, and Islamic banking. The Islamic Financial Services Board (2018) reported that the overall value of the Islamic financial services business exceeded USD2 billion marginally. In many countries, Islamic banks and Commercial banks coexist and function in a dual banking system (Rizvi, 2018).

Izzati (2017) said it encourages a big number of Islamic banks in Malaysia to 
discover alternatives and ways to boost their profitability over year. Profitability changes can have a major impact on the economy since it could contribute significantly to economic success. Investment and saving decisions generally allow banks to impact earnings. Increased profit increases banks' performance and provides greater flexibility in the source of corporate investment financing. The Islamic finance (2017) has mentioned that increased competition has broadened the Islamic product offering, making it more accessible to a wider range of Muslims. An attempt by Islamic banks in the early 2000s to make Shariah-compliant products more commercially appealing was a major change in the sector.

In Malaysia, the Islamic banking sector has made important contributions to the advancement of the entire financial system, which has an impact on economic growth (Hassan, 2011). The banking system, comprising Islamic banks, Islamic banks, is also one of the main sources of financing that supports economic activities in Malaysia other than Commercial banks and Investment banks. Islamic banking is referring to a banking system that complies with Shariah law which is unlike the conventional and foreign banking system. The Islamic bank in Malaysia has been established and develop in 1983 which they introduced the Islamic finance product to Muslim people as followed by Shariah Laws. According to (Bank Negara Malaysia, 2017) at the end of 2017, Malaysia had 16 Islamic banks, up from just two in 2001 which 11 out of 16 is local institutions and the remaining 5 are foreign ownership and 3 out 16 Islamic Banking that are chosen is Maybank Islamic Berhad the country's largest supplier of Islamic financial services, with estimates of RM19.53 billion in 2012 of Shariah-compliant funds, with Bank Islam Malaysia Berhad coming in second as the region's second largest bank hence the first Islamic bank (Choong, 2012) and followed by CIMB Islamic Bank Berhad and its leaders have been a recipient of several awards such Best Islamic Financial Institution of Southeast Asia and Best Islamic Bank in Asia. Plus, CIMB Islamic also a world leader in Islamic finance.

\section{Purpose of the Study}

Nowadays, Islamic banking has grown in popularity because it is important to Malaysians. Since Malaysia is primarily made up of Muslims, they choose Islamic banking over conventional banking because it is a shariah-compliant financial sector. This research will look at the importance of bank size, risk management, GDP and other factors that influence the success of Islamic banks. According to (Sultana, 2010), the first Islamic banking in Malaysia was established in 1983 with the establishment of Bank Islam Malaysia Berhad (BIMB), which was recognised by Bank Negara Malaysia. Many conventional banks in Malaysia had explored Islamic banking and they have gradually created and given Islamic financial services to Muslims.

Islamic banks will share risks and profits by delivering a deal to the customer, while most conventional banks seek higher liability with a zero-risk structure. One of the key objectives at the creation of the Islamic Bank is to contribute to social justice in societies. This is because (Bove, 2015) claims that Islamic banks have the "no risk or no profit" philosophy. Implying that, risks are split proportionately between both parties, a customer and a bank. In addition, Islamic banks have financial instruments for companies such as Mudaraba and Musharaka which means the provision of funds and participation in the activity (Bove, 2015). Another advantage of Islamic banking is its contribution to reduce dangerous products and to 
enhance environmental protection. It can be regarded as a more ethical advantage, but its social impact is also crucial.

Furthermore, Islamic banks have grown in popularity among customers in recent years. According to the Bank Negara Malaysia (BNM), overall financing from Islamic banks is expanding year after year. Total market financing from Islamic banks was RM 78.5 billion in 2006, while total deposit in Islamic banks was RM 99 billion. In 2010, both figures increased by more than 100 percent. In 2010, the entire lending amount was RM 162 billion, and the total deposit amount was RM 217 billion, according to (Abduh, 2014). Furthermore, (Chung, 2013) has identified this study as a reference for the Malaysian government in accomplishing the goal of transforming Malaysia into an Islamic hub.

The impact of Islamic banking performance is significant since it will lead to rises and falls in Islamic bank profitability. The purpose of this study is to examine the performance of Islamic banking using data from 2011 to 2020. Islamic banking performance can be measured using factors such as bank size, risk management and GDP. It is quantifiable to see if bank size, risk management and GDP have an impact on Islamic banking performance. Our findings can help Islamic banks focus on and monitor the elements that have a significant impact on their profitability.

\section{Literature Review \\ ROA and ROE Concept}

The primary aim of investment is to generate a profit. Return on investment is determined by adjustments in the price of share at the conclusion of the investment cycle as well as dividends earned. Return on Asset (ROA) is an indicator of the profitability of some organization in relation to the cumulative value of the assets. It demonstrates how effectively management uses its tools to obtain profits. (Anas, 2016). The number of net profits recovered as a proportion of shareholders equity is known as return on equity (ROE). It determines a company's viability by showing how much value it earns from the capital spent by shareholders (Anas, 2016).

\section{Return on Asset}

Return on assets (ROA) is a metric for determining a bank's profitability. It is determined by dividing gross net profits by total assets. ROA is the most commonly used metric and researchers in many countries have used it to study bank profitability, for example the studies conducted by (Hamidi, 2012). In line with (Obamuyi, 2013), they discovered that ROA is superior to ROE because ROA measures profits produced per unit of asset, which represents a bank's capacity to benefit from both financial and real assets, whereas ROE ignores financial leverage.

According to Bashir (2003), the drawbacks of employing ROE include that it is derived by dividing total net income by total equity, which implies that ROE only represents how well a bank uses shareholders' capital to make profits, but it ignores financial leverage or debt. In other words, a high ROE does not always imply a big profit margin in a bank because high ROE might be due to the lower capital or equity. Since ROE simply reveals how shareholders' money are utilised to produce profits and ignores liabilities like borrowed funds and bonds, ROA is preferable because its denominator is total assets, which already includes liabilities and equity. Some researchers argue about using ROA as an indicator of a bank's profitability. (Sofoklis, 2009) argues that because it eliminates off-balance-sheet operations, ROA may be 
skewed.

\section{Return on Equity}

Return on equity is a metric that measures a company's ability to obtain profit from its share capital, and it primarily focuses on internal performance to determine shareholder value. Furthermore, it is an important ratio that reflects the bank's earnings efficiency (Mahdi, 2019). This evaluation focuses mostly on internal performance reflecting the worth of shareholders (Mahdi, 2019). According to Hajer and Anis (2018), the corporate stakeholders believe that return on equity is a dependable indicator for the performance of the company. According to Hakimi (2016), a good level of return on equity indicates a high level of profitability with limited equity. As a result, a lower net income might provide a greater return on equity from an uncertain equity base, which is critical for the banking industry due to its high leverage (Aktan, 2019).

Aktan (2019) claims that even a small quantity of net income can result in a large return on equity. This is especially significant for highly leveraged financial institutions like banks. It indicates the profit made on a shareholder's investment in the company. The return on equity ratio, which is widely utilised by investors, is a key indicator of a company's financial performance. According to Aktan (2019), while highly regarded as a profitability indicator, the return on equity metric does have a recognized weakness. Investors should be mindful that a company's capital structure with a disproportionate level of debt will have a smaller equity basis. Siddik (2017) research is limited to the banking business and the researcher measures bank performance using both return on equity and return on assets.

\section{Credit Risk}

Credit risk is the potential that credit customers may be unable or unable to repay the contractual debt in full or on the maturity date, causing banks to lose wholly or partially on their outstanding loans. Several proxies for credit risk have been employed in prior research. According to Abiola and Olausi (2014); Marshal and Onyekachi (2014), credit risk, as assessed by the percentage of non-performing loans to loans and advances, has a positive association with Islamic banks' return on assets (ROA). This conclusion is remarkable because, theoretically, non-performing loans should have a negative association with the bank's profitability; that unusually positive association indicates poor credit risk management.

Furthermore, the positive relationship emerges from the bank's decision to pass on the expense of loan losses to other customers by charging them higher interest rates on loans. Dash and Agyei (2012) suggested that credit risk is significantly and positively associated with bank profitability, and their findings indicate that increased credit risk benefits Ghanaian banks by bringing in more revenue. This is due to the fact that excessive credit risk will result in prohibitively expensive lending/interest rates, fees, and commissions. Researchers discovered a negative link between credit risk and bank profitability. Higher-risk loans necessitate greater loan loss provisions, making it difficult for banks to optimise earnings as they reserve more capital for loan losses (Abdullahi, 2013). As a result, the larger the credit risk (loan loss provision-to-total loans), the lower the bank's profitability.

Moreover, Sufian and Chong (2008) emphasised that banks failed to spot impaired assets and provide reserves to write down the assets, which negatively impacted the bank's profitability. Mustafa (2013) agrees that a lack of management skills to oversee lending operations will eventually result in a bigger loan loss provision being required to cover the risk, and hence the loan loss provision-to-total loan ratio will have a negative impact on the 
bank's profitability. According to Weerasinghe and Perera (2013), the expected sign of this variable between credit risk and bank profit is not supported by their regression results. As a result, they determined that credit risk had no bearing on a bank's profitability.

\section{Bank Size}

The size of a bank is used to analyse the size of the bank's profitability, and is also used to demonstrate the existence of scale economies (Embaya, 2013). According to industrial economic theory, if economies of scale exist in an industry, bigger institutions can become more efficient and produce goods or services at reduced costs, resulting in increased profits. Since dependent variables and independent variables are stated in ratios, the total assets should thus be logged so that their unit measurement is consistent with other ratios (Gafoor, 2011).

Larger banks, for example, are able to lower the cost of acquiring and processing data, resulting in increased profitability. According to the findings, which are also noted by Jabbar (2014), larger banks have a large number of branching networks around the nation and are able to offer credit more effectively. Additionally, larger banks are able to experiment with different forms of portfolio to gain higher diversified profits. This is supported by Abduh and Idrees (2013), who state that larger banks have better loan diversity as well as greater access to capital markets than small banks.

However, other researchers think that if banks are exceedingly large and reach an optimal size, diseconomies of scale will set up, and eventually expanding bank size would have a negative impact on bank profitability (Obamuyi, 2013). According to Almazari (2014)'s studies in Europe, expanding bank size would face diminishing marginal returns, causing average earnings to drop with size. Furthermore, Obamuyi (2013) stated that banks with excessively big sizes may face issues such as bureaucratic procedures, agency costs, and managerial inefficiencies. According to Edore (2014), minimal bank size may be related to poor asset management.

\section{Gross Domestic Product (GDP)}

Gross Domestic Product (GDP) is a measure of a country's entire economic activity (Elvis, 2020). Changes in GDP represent changes in consumption, investment, government expenditure, and net export; hence, changes in GDP are likely to alter the supply and demand for loans and deposits. Because of the undeveloped non-bank financial institutions in the nation, home savings are mostly being made available to the banks. From the bank's point of view, better economic growth encourages banks to lend greater margins and to increase their asset quality (Said \& Tumin, 2011).

Some studies, on the other hand, suggest that GDP is not always related to a bank's profitability. Staikouras and Wood (2012) discovered that GDP growth is inversely associated with bank profitability in the case of European banks. They explained that nations with greater GDP often have a banking system that functions in a mature setting, resulting in a highly competitive level of interest and profit margin. In other words, due to increased rivalry in the banking business, banks were unable to benefit and profit from economic expansion.

However, the GDP effect was discovered to be insignificantly connected to bank profitability, and its significance subsequently became equivocal for some researchers. Empirical study undertaken by Abduh and Idrees (2013) in Malaysia and Kaddumi (2011) in Jordan, for example, suggest that real GDP has a negligible positive impact on a bank's profitability. According to Ramadan et al. (2011), banks have failed to gain from economic 
expansion due to the arrival of new banks, which has increased competition.

\section{Methodology \\ Types of Investigation}

The type of investigation that will be used in this research are two forms which are correlation and causal. The distinctive correlation between causal studies can be further clarified in this research. For instance, these studies were to clarify and to investigate the effect of the relationship between profitability in which the ROA and ROE have on the internal and external factors which are bank size, risk management and GDP that have been used in this research.

\section{Sampling}

According to Osman (2011), since the list of Islamic banking customers in Malaysia is unavailable due to legal and privacy concerns, a non-probability sampling methodology was used in this analysis. The sample that has been used in this analysis is the sample of the bank profitability Islamic banks which is taken from the financial statement of the Islamic bank institution's annual report. The period of the analysis is from 2011 to 2020 with data collected in ten (10) years of the selected Islamic bank institutions. For this analysis, a panel data regression model has been used to analyze the data whether there is a positive or negative relationship between dependent variables and independent variables.

\section{Data Collection}

The secondary data will be used in this research study which will be gathered from secondary sources. Secondary quantitative data is the facts collected from the sources that already exist or data that has been collected by someone else before this for a different purpose. Such data can be accessed through the Internet, annual reports, databases, journals, articles and others. According to Mahdi (2019) there are primarily two reasons why this type of study uses secondary data, firstly due to a time constraint which is secondary data are simple to obtain which allowing this research to be completed on time and secondly, there is no question that the annual report of the banks contains falsified information due to adequate supervision by appropriate Malaysian authorities. In data collection, we first distinguished the banks involved in this research. The data collected are the three (3) selected Islamic banking listed by Bank Negara Malaysia and other relevant websites.

\section{Framework}

The development of a theoretical framework gives readers a better insight and clearer picture of what the researcher is trying to achieve in their research. This is primarily used to determine whether or not there is a significant relationship between independent and dependent variables. This research will be based on this theoretical framework. The model focuses on the determinants of the bank size, risk management, gross domestic product (GDP) in terms of return on assets and equity on the financial performance of the Islamic Bank. Each of these independent and dependent variables will be discussed. 
INDEPENDENT VARIABLES

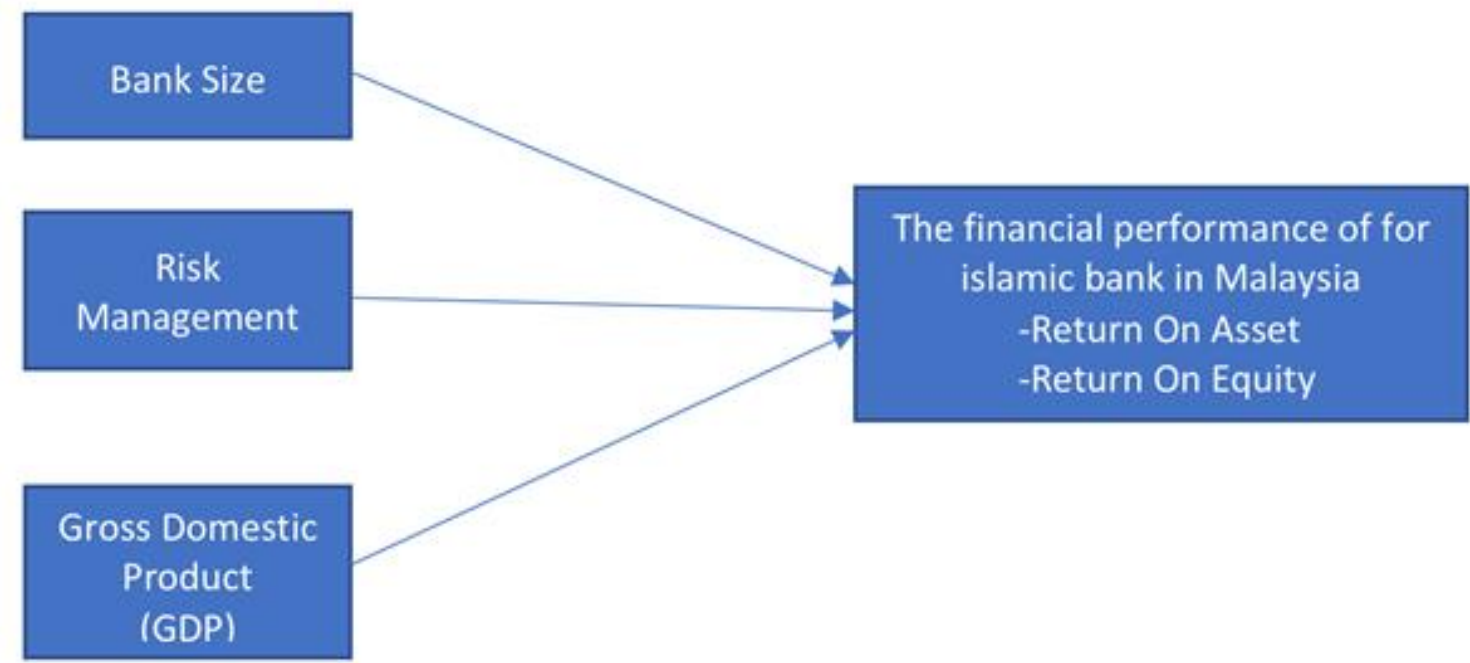

\section{Result}

\section{Regression Analysis}

The evaluation of regression is used to determine if independent factors explain the influence of the dependent variable when there are more than two variables. The obtained regression analysis results can be explained by examining the econometrics formula and the value of the coefficient is used in the econometric equation.

Based on the regression analysis results, the independent variables of credit risk and bank size showed a negative correlation between the return on asset and return on equity of Islamic banks in Malaysia. However, the independent variables of gross domestic product showed a positive correlation for both dependent variables of return on asset and return on equity.

The F-statistic value for return on assets is 2.4503 , and the F-statistic P-value is 0.0860 . Because the value has a significance level of more than $5 \%$, the null hypothesis must not be rejected. This suggests that at least one of the factors can be used to evaluate the financial firm's efficiency. Meanwhile, the F-statistic value for return on equity is 2.4774 , with an Fstatistic P-value of 0.0836 . Because the value has a significance level of more than $5 \%$, the null hypothesis must not be rejected.

The value of $\mathrm{R}$-squared for return on assets is 0.2204 , which suggests that the variation of independent variables such as credit risk, bank size, and gross domestic product can explain 22.04 percent of the variance in the company return on assets. The adjusted $R$-squared value is 0.1305 which indicates 13.05 percent. This has the same significance as R-squared, where the variability of independent variables can explain 13.04 percent of the variance in the financial firm's return on assets.

Meanwhile, the R-squared value for return on equity is 0.2223 , indicating that the variation of independent variables such as credit risk, bank size, and gross domestic product can explain 22.23 percent of the variance in the Islamic banks return on assets. The adjusted R-squared value is 0.1325 which indicates 13.25 percent. This has the same significance as $R-$ squared, where $13.25 \%$ of changes in the return on equity are explained by the credit risk, 
bank size and gross domestic product, adjusted degree of freedom. By using each of the variables, more information will be clarified.

As a result, the R-squared can be explained by the effect on independent variables of return on asset and return on equity with dependent variables are significant with the variables as it fits perfectly well because the range of R-squared for return on asset and return on equity between 0 to 1 .

The first component is the credit risk. The figure indicates that the credit risk coefficient for return on asset and return on equity is -0.0015 and -0.0199 respectively. It is assumed that for every 1 percent increase in credit risk, a 0.15 percent decrease in return on asset. It also indicates that for each one percent increase in the credit risk, a 1.99 percent decrease in return on equity for the Islamic banks assumes that other factors will remain constant. For the variable of return on asset, the probability value for credit risk is 0.1196 . Meanwhile, the probability for the return on equity is 0.0940 . This indicates that both probability is larger than 5 percent significance level. This suggests that the null hypothesis is not rejected, and changes in credit risk have a negligible effect on return on assets and return on equity. The finding of insignificance is consistent with the previously conducted studies by (Mahdi, 2019; Ramazan \& Gulden, 2019).

The bank size is the second component. The table shows that the bank size coefficient for return on asset is -0.0003 which is -0.03 percent and bank size coefficient for return on equity is -0.0039 which is -0.39 percent. It is assumed that for every 1 percent rise in bank size, the return on assets of Islamic banks in Malaysia will decline by 0.3 percent. Meanwhile, research shows that for every 1 percent rise in bank size, the return on equity for Islamic banks decreases by 0.39 percent, assuming all other factors remain constant. For the first dependent variable of return on asset, the probability value for bank size is 0.3887 . Meanwhile, the probability for the second dependent variable of return on equity is 0.4211 . This indicates that both probability is larger than 5 percent significance level. This suggests that the null hypothesis is not rejected, and changes in bank size have a negligible effect on return on assets and return on equity. The bank size has an insignificant impact on return on equity. The finding of insignificance is consistent with the previously conducted studies by (Hamza, 2017; Haron, 2004; Hassan \& Bashir, 2003).

The final component is the gross domestic product (GDP), which shows that the GDP

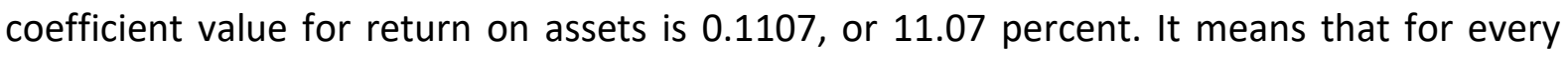
percentage increase in the gross domestic product, the return on assets in Malaysian Islamic banks will increase by 11.07 percent, assuming all other factors remain constant. Meanwhile, the return on equity coefficient value for gross domestic product is 1.1398 , or 113.98 percent. It means that for every percentage increase in the gross domestic product, the return on equity in Islamic banks in Malaysia will increase by 113.98 percent, assuming all other factors remain equal. The probability figure, however, is 0.1677 and 0.2330 for return on asset and return on equity respectively, which is higher than 5 percent significance point. This suggests that the null hypothesis is not rejected, and changes in GDP have a negligible effect on return on assets and return on equity. The result of insignificance is consistent with the findings of other studies by (Ramazan \& Gulden, 2019; Rashid \& Jabeen, 2016).

\section{Conclusion}

Since 1983, Islamic banking has risen to prominence and expanded significantly, with a total of 16 Islamic banks operating in Malaysia Isa (2020). The purpose of our paper is to investigate the relationship between these variables and the profitability of Islamic banks in 
Malaysia. The dependent variable that is being used is Return on Asset (ROA) and Return on Equity (ROE). The goal of this research was to determine how these independent variables influenced the profitability of Malaysian Islamic banks. Maybank Islamic Banking, CIMB Islamic Banking, and Bank Islam Malaysia Berhad were chosen as the three Islamic banks.

Based on analysis in chapter 4 for bank size and profitability, the result shows no significant data. This result already got supported by previous researchers, by Redmond (2007). They divided banks into five groups based on their asset size, using the ROE ratio as a measure of profitability, and discovered that profitability and bank size had a negative significant connection. This study is in line with the studies by Ahmed (2011) that stated the impact of bank size on profitability is negligible since smaller banks generally want to develop quickly, even if it means sacrificing profitability. This is because the larger the size of the bank, the higher total income accrued to the bank.

Yong (2012) states that the total asset of the bank served as a proxy for the size of the bank. Islamic banks are not permitted to engage in high-risk activities as a result of Islamic banking regulations; as a result, Islamic banks can increase their total assets by increasing the amount of money they lend to customers. Prior to increasing the amount of money that banks lend to consumers, banks should raise the amount of money that customers deposit with them, allowing them to have more money available to lend to customers later.

Other independent variables, which is GDP also show no significance with profitabilities. The Gross Domestic Product (GDP) is a measure of overall economic activity. According to Ashraf (2012) who said, GDP is not a significant measure, but it has a detrimental impact on the profitability of Islamic banks. Because of the insignificant, when the Non-Profit Loan/Total loan (NPL/TL) ratio grows, the capital utilised by banks to carry out their investments and operations decreases, and therefore the profit of banks decreases. As a result, it is recommended that banks focus on high-profit-generating activities that will allow their capital to grow quickly in their operations.

This study is in line with the studies by Anitha (2019) who state that GDP is insignificant with the profitability of Islamic banks because they are unable to retain and hold earnings for a lengthy period of time, such as in one year. To be more specific, it might be caused by regulatory limitations, less business activity and charged less proportion of tax on profit. Kok (2012) found that despite the fact that the results reveal that the association is modest, economic growth and GDP may still have an impact on the profitability of financial institutions. So, in order to boost the profit of Islamic banks, policymakers must first increase the overall GDP of a country. By lowering the tax rate, it may contribute to the growth of the economy, which in turn increases the profitability of Islamic banks.

The last variable is credit risk. It also shows insignificant results. According to (Ahamd, 2015), credit risk factors are insignificant when it comes to ROE. If banks rely heavily on debt to fund their operations, their profitability will suffer, and a higher debt ratio means a higher debt value on the liabilities side of their balance sheet, resulting in a reduced profit margin over time. This may be explained by the fact that unexpected loan and advance lending accounts for the majority of the financial risk that banks confront. This study is in line with Paolucci (2016) who found that higher profitability ratios imply a worse credit quality which is low profit. As a result of the above statement, it appears that a higher degree of credit risk is associated with lower profitability.

Lim (2015) had mentioned that credit risk variables may also be included for the management of banks and policy makers. The results in this research show that the credit risk is insignificant to the profitability of the bank. It is therefore recommended that the 
management of banks and policy makers establish a plan that helps banks to reduce their credit risk. In order for the bank to multiply risk or minimise credit risk, banks should practice in analysing credit risk by screening potential borrowers and try to access collateral value continuously (Soh, 2015).

Future research could broaden the scope of target samples and conduct comparative analysis with foreign banks to gain a better understanding from many perspectives. Future studies could also improve data collection and take qualitative effects into consideration to increase the reliability of related industries (Chan, 2019). According to Jing (2019), future researchers are encouraged to use a variety of methodologies to estimate the data's outcome. Since E-View (Electronic View) was used to regress the data in this study, other similar tools such as Stata, Statwing, and SPSS are a useful choice for researchers to undertake appropriate tests to improve the study's reliability.

\section{References}

Abduh, M., \& Alias, A. (2014). Factors Determine Islamic Banking Performance in Malaysia: A Multiple Regression Approach. Journal of Islamic Banking and Finance, 44- 54. https://core.ac.uk/download/pdf/300425539.pdf

Aktan, B., Turen, S., Tvaronavičienè, M., Celik, S., \& Alsadeh, H. A. (2019). Corporate Governance and Performance of the Financial Firms in Bahrain. Polish Journal of Management Studies, 17(1), 39-58. https://doi.org/10.17512/pjms.2018.17.1.04

Bank Negara Malaysia. (2017). Retrieved December 1, 2017, from Financial Stability: http://www.bnm.gov.my/?ch=li\&cat=islamic\&type=IB\&lang=en

Bashir, A. M. (2003). Determinants of profitability in Islamic banks: Some evidence from the Middle East. Islamic Economic Studies, 11(1), 31-54.

Choong, Y. V. (2009). Performance of Islamic Commercial Banks in Malaysia: An Empirical Study.

Hajer, C., \& Anis, J. (2018). Analysis of the Impact of Governance on Bank Performance: Case of Commercial Tunisian Banks. Journal of the Knowledge Economy, 9(3), 871-895. https://doi.org/10.1007/s13132-016-0376-6

Hakimi, A., Rachdi, H., Mokni, R. B. S., \& Hssini, H. (2016). "Do board characteristics affect bank performance? Evidence from the Bahrain Islamic banks." Journal of Islamic Accounting and Business Research, 85(3), 295-301. https://doi.org/10.1134/s0026261716030140

Haron, S. (2004). Determinants of Islamic Bank Profitability Working Paper Series 002 Determinants of Islamic Bank Profitability. The Global Journal of Finance and Economics. USA, 1(1). Retrieved from:

https://ie.um.ac.ir/images/329/Articles/Others/Latin/Determinants\%20of\%20lslamic \%20Bank\%20Profitability.pdf2.pdf

Hassan, K., \& Bashir, M. (2003). Determinants of Islamic Banking Profitability, International Seminar on Islamic Wealth Creation, University of Durham, U.K, 7-9 July, 2003.

Hassan, M. K., Sanchez, B., \& Yu, J. (2011), "Financial development and economic growth in the organisation of Islamic conference countries", JKAU: Islamic Econ, Vol. 24 No. 1, pp. 145-172.

Islamic Financial Services Board. (2018), Islamic Financial Services Industry Stability Report 2018 [Online] Available from: https://www.ifsb.org/download.php?id=4811\&lang=English\&pg=/index.php [Accessed on 15 July 2019]. 
Mahdi. (2019). Corporate governance and Bank Performance: Conventional VS Islamic Bank in Malaysia. Universiti Tunku Abdul Rahman.

http://eprints.utar.edu.my/3597/1/Research_Project_Muhammad_Mahdi_Billah.pdf

Obamuyi, T. M. (2013). Determinants of bank's profitability in a developing economy: Evidence from Nigeria. Organizations and Markets in Emerging Economies, 4(2), 97109.

Ramazan Ekinci, Gulden Poyraz. (2019). The Effect of Credit Risk on Financial Performance of Deposit. Procedia Computer Science, 979-987

Rashid, A., \& Jabeen, S. (2016). Analyzing performance determinants: Conventional versus Islamic banks in Pakistan. Borsa Istanbul Review, 16(2), 92-107.

Siddik, M. N. A., Kabiraj, S., \& Joghee, S. (2017). Impacts of Capital Structure on Performance of Banks in a Developing Economy: Evidence from Bangladesh. International Journal of Financial Studies, 5(2), 13. https://doi.org/10.3390/ijfs5020013 